\title{
PENGEMBANGAN HOME AUTOMATION SYSTEM (HAS) UNTUK MENGENDALIKAN PERANGKAT LISTRIK BERBASIS BLUETOOTH MENGGUNAKAN APLIKASI ANDROID
}

\author{
M. Santo Gitakarma ${ }^{1}$, Agus Adiarta ${ }^{2}$, L. P. Ary Sri Tjahyanti ${ }^{3}$ \\ 1Jurusan D3 Teknik Elektronika, FTK UNDIKSHA \\ 2Jurusan S1 Pendidikan Teknik Elektro, FTK UNDIKSHA \\ ${ }^{3}$ Universitas Panji Sakti Singaraja, UNIPAS
}

e-mail: santo@undiksha.ac.id, agus.adiarta@undiksha.ac.id, ary.tjahyanti@unipas.ac.id

\begin{abstract}
Abstrak
Sistem smart home atau Home Automation System (HAS) merupakan istilah referensi yang digunakan secara luas untuk sistem pengontrolan, monitoring, dan fungsi-fungsi otomasi di dalam rumah. HAS umumnya memerlukan aplikasi smartphone atau portal web sebagai antarmukanya. Perangkat listrik atau divais dapat dikendalikan dengan saklar, timer, sensor atau kontrol remote. Dalam paper ini dijelaskan modul untuk mengendalikan divais dengan aplikasi dari smartphone melalui koneksi bluetooth yang bernama Android Bluetooth Control Device (ABCD). Pembuatan modul ini dikemas secara portable dan dapat digunakan dalam pembelajaran di kelas atau didemonstrasikan kepada masyarakat yang ingin mengetahui prinsip kerja modul $A B C D$ ini. Pendekatan yang digunakan adalah pengendalian 8 buah perangkat yang terdiri dari 4 buah lampu dan 4 perangkat listrik tambahan. Modul dikendalikan dengan aplikasi smartphone melalui koneksi bluetooth menggunakan bluetooth HC05 yang bekerja pada frekuensi $2,4 \mathrm{GHz}$ dengan jangkauan maksimal $10 \mathrm{~m}$. Modul $A B C D$ dapat digunakan untuk memudahkan pengguna dalam mengendalikan berbagai perangkat listrik di rumah.
\end{abstract}

Kata kunci: Android, bluetooth, remote control, otomasi rumah

\begin{abstract}
Home Automation System (HAS) is a widely used reference term for a system of controlling, monitoring, and home automation functions. HAS generally required a smartphone application or web portal as its interface. The electrical devices can be controlled by a switch, timer, sensor or remote control. In this paper, we describe the module for controlling devices with applications from smartphones via a Bluetooth connection called Android Bluetooth Control Device (ABCD). This module is packaged portable and can be used in classroom learning or demonstrated to people who want to know the working principle of this module. The approach used is controlling 8 devices consisting of 4 lights and 4 additional devices. The module is controlled with smartphone application via Bluetooth using Bluetooth HC-05 which works on $2.4 \mathrm{GHz}$ frequency with a maximum range of $10 \mathrm{~m}$. ABCD module can be used to facilitate the user in controlling various electrical devices at home.
\end{abstract}

Keywords : Android, bluetooth, remote control, home automation

\section{PENDAHULUAN}

Saat ini banyak rumah yang ditempati oleh keluarga termasuk adanya orang tua yang telah lanjut usia maupun sanak keluarga yang cacat fisik di dalamnya. Disaat anggota keluarga bekerja dan anakanak sekolah, sering kali didapati orang tua yang telah lanjut usia atau anggota keluarga yang cacat berada di rumah tanpa bantuan. Orang lanjut usia tidak ditempatkan di panti jompo yang ada penjaganya, dan orang yang cacat masih memerlukan bantuan orang lain untuk menjaganya. Kondisi demikian memerlukan sentuhan teknologi pada rumah tinggal untuk memudahkan penghuni rumahnya mengakses perangkat 
listrik yang ada. Dengan kemajuan teknologi smartphone dan adanya peralatan smart home yang dijual dapat memudahkan pemilik rumah menjadikan rumahnya otomatis atau dapat dikendalikan dengan mudah.

Otomasi di lingkungan sekitar terutama di rumah pada jaman modern ini telah membuat manusia bekerja secara nyaman dan efisien. Ada peningkatan yang signifikan dalam lingkup tugas-tugas rutin yang dilakukan seseorang dan tugas tersebut saat ini dapat dilakukan secara otomatis. Setiap orang saat ini tidak lepas dari ketergantungan terhadap smartphone atau mobile phone. Dengan bantuan penggunaan smartphone dan fungsi-fungsi di dalamnya, beberapa tugas pekerjaan rumah dapat diselesaikan oleh setiap individu. Otomasi di dalam rumah sering disebut sebagai smart home atau smart house dengan sistemnya yang dikenal dengan Home Automation System (HAS).

HAS dapat membuat berbagai perangkat listrik di rumah beroperasi dengan mudah dan hemat energi. Penelitianpenelitian sebelumnya yang berhubungan dengan sistem otomasi rumah atau HAS menggunakan bluetooth yang dikemukakan oleh (Sriskanthan, Tan, \& Karande, 2002), yang memiliki kemiripan dengan penelitian ini antara lain sebagai berikut. (Panth \& Jivani, 2013) membuat modul HAS untuk mengendalikan 8 relay yang dikendalikan pengguna melalui smartphone dengan koneksi bluetooth. (Pandya, Mehta, Jain, \& Kadam, 2016) melakukan penelitian penggunaan arduino yang dapat memproses sensor gas dan temperatur, mengontrol relay pada perangkat listrik, dan mengirimkan sinyal bluetoothke smartphone android. Perintah dari pengguna menggunakan suara melalui aplikasi di android. (Harikrishnan, Nikhil, Roy, \& Mathew, 2017) mendesain HAS dengan arduino BT board yang menerima sinyal data melalui koneksi bluetooth untuk mengontrol beberapa relay secara otomatis maupun manual. Masih banyak lagi aplikasi HAS, seperti yang diteliti (Demeure, Caffiau, Elias, \& Roux, 2015) oleh ada 47 bangunan smart home yang diklasifikasikan menjadi 10 semi struktur HAS.
Konsep smart home yang ditawarkan disini adalah membangun suatu sistem smart home dengan bantuan penggunaan smartphone yang dapat dikoneksikan melalui bluetooth pada suatu modul. Penelitian ini merupakan pengembangan penelitian sebelumnya (Gitakarma, Indrawan, \& Adiarta, 2016) yaitu pengembangkan modul prototipe smart home dengan mikrokontroler AT89C2051 yang dapat mengendalikan 4 buah relay yang disambungkan pada 4 buah perangkat listrik berupa lampu. Hasilnya penelitiannya dilakukan dengan pengukuran jarak maksimal dan jarak jangkauan rata-rata koneksi bluetooth sekitar $10 \mathrm{~m}$.

Dari beberapa penelitian yang telah dilakukan dari para peneliti sistem otomatis rumah, dapat dikatakan sistem HAS ini masih sangat update dibicarakan dikalangan peneliti dan masih banyak variasi yang dapat dikembangkan baik dari sistem aplikasi maupun perangkat keras yang digunakan.

Beberapa aplikasi yang berkaitan dengan pengendalian divais terdapat di dalam google apps untuk mengendalikan perangkat yang menggunakan koneksi bluetooth. Contoh aplikasi-aplikasi ini antara lain digunakan untuk pengendali robot mobil, pengendali arduino, dan pengendali relay untuk perangkat listrik. Khusus untuk aplikasi android bluetooth sebagai pengendali perangkat listrik juga ada beberapa jenis sesuai dengan rangkaian elektronika pengendali alat yang dikembangkan oleh pengembang aplikasinya. Sehingga untuk menggunakan aplikasi ini pengguna diharapkan mengetahui karakteristik data yang dikirimkan ke bluetooth, jenis bluetooth yang digunakan dan bagaimana rangkaian pengendali perangkat listrik menggunakan koneksi bluetooth.

Disini peneliti akan mengembangkan sistem otomasi rumah tinggal dimana perangkat listrik yang digunakan dikendalikan melalui smartphone berbasis android. Aplikasi android yang digunakan yaitu Bluetooth Control Device. Aplikasi ini harus dikoneksikan dengan rangkaian elektronika yang menggunakan bluetooth tertentu untuk menerima data dan diproses dalam mikrokontroler berbasis Arduino. 
Namun penggunaannya tidak hanya pada mikro Arduino, dapat juga diaplikasikan pada mikrokontroler AT89C2051 dengan desain yang memperhatikan karakteristik data-data bluetooth yang ada di smartphone android. Dari hasil penelitian yang telah dilakukan sebelumnya, hal yang penting dalam mendesain suatu sistem otomasi rumah adalah kemampuan sistem untuk dapat diakses dalam suatu jaringan atau dapat juga diakses melalui internet. Peneliti disini mencoba menggambarkan sistem otomasi rumah yang dapat diakses melalui internet dengan menyempurnakan hasil penelitian sebelumnya yang tanpa memperhatikan aspek dalam kemampuan akses internet. Dengan menggunakan aplikasi tambahan yang dapat didownload dari google apps, kemampuan sistem yang ditawarkan ini dapat diakses melalui internet sehingga memungkinkan pengguna menikmati fasilitas sistem otomasi rumah (HAS) dari luar rumah atau dari mana saja selama ada akses internet. Namun yang menjadi syarat disini adalah rumah yang memiliki sistem HAS haruslah ada akses internet di dalamnya.Semua teknik, desain, cara kerja dan pengujiannya dari sistem HAS yang ditawarkan disini akan dijabarkan pada bagian berikutnya.

\section{METODE \\ A.Desain Sistem}

Smart home atau yang biasa kita sebut rumah pintar merupakan rumah atau gedung yang dilengkapi dengan teknologi tinggi yang memungkinkan berbagai system dan perangkat di rumah dapat berkomunikasi satu sama lain untuk memenuhi kebutuhan pengguna terutama orang lanjut usia dan orang yang cacat (Ramlee, Othman, Leong, Ismail, \& Ranjit, 2013). Smart home berisi berbagai sistem dan perangkat, seperti pemanas sentral, alarm kebakaran, televisi dan lampu yang menyampaikan informasi dan perintah antara satu dan lainnya. Smart home system dalam beroperasi dibantu oleh komputer untuk memberikan segala kenyamanan, keselamatan, keamanan dan penghemat energi yang berlangsung secara otomatis dan terprogram melalui komputer pada gedung atau pun rumah tinggal kita. Smart home system dapat digunakan untuk menggendalikan hampir semua perlengkapan dan peralatan di rumah, mulai dari pengaturan tata lampu hingga berbagai alat-alat rumah tangga, yang perintahnya dapat dilakukan dengan menggunakan suara, sinar infra merah atau kendali jarak jauh (remote).

Smart home dalam penelitian ini mengacu pada kemampuan kendali jarak jauh (remote) menggunakan sinyal bluetooth untuk menghidupkan dan mematikan perangkat listrik yang ada di dalam rumah tinggal. Teknologi bluetooth sangat jarang digunakan untuk remote di rumah, namun teknologi bluetooth tersedia dalam smartphone yang umum digunakan setiap orang saat ini. Sehingga dengan memanfaatkan teknologi bluetooth yang tersedia dalam smartphone maka dapat dibuat sebuah modul yang memancarkan sinyal bluetooth dan sinyalnya dapat ditangkap oleh smartphone. Sistem komunikasi seperti ini dapat digunakan untuk mengendalikan relay-relay yang terhubung dalam perangkat listrik rumah tinggal.

HAS atau Home Automation System seperti pada Gambar 1 dapat didesain dengan beberapa model perangkat keras dan perangkat lunak. Tidak ada model yang baku, namun yang terpenting adalah bagaimana suatu sistem yang melibatkan beberapa komponen elektronik termasuk mikrokontroler yang didesain dapat mengendalikan relay maupun membaca sensor dan dapat mengirim maupun menerima sinyal koneksi dari bluetooth, wifi maupun koneksi lainnya yang berhubungan dengan antarmuka dari sistem smart divais seperti smartphone Android, iOS, atau Windows.

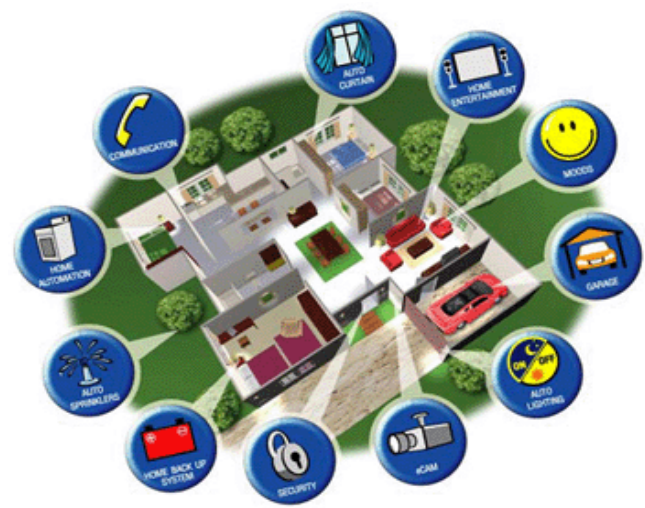

Gambar 1. HAS dengan berbagai fitur

Jurnal Sains dan Teknologi | 159 
Relay yang dikendalikan dari mikrokontroler kemudian dihubungkan dengan perangkat listrik secara pararel dengan saklar manual sehingga event ONOFF dapat terjadi melalui cara manual pada saklar listrik atau dari kondisi relay yang didapat dari data bluetooth yang diproses di mikrokontroler.

Sistem HAS yang didesain pada penelitian dengan modul Android Bluetooth Control Device (ABCD) disini dapat digambarkan seperti berikut.

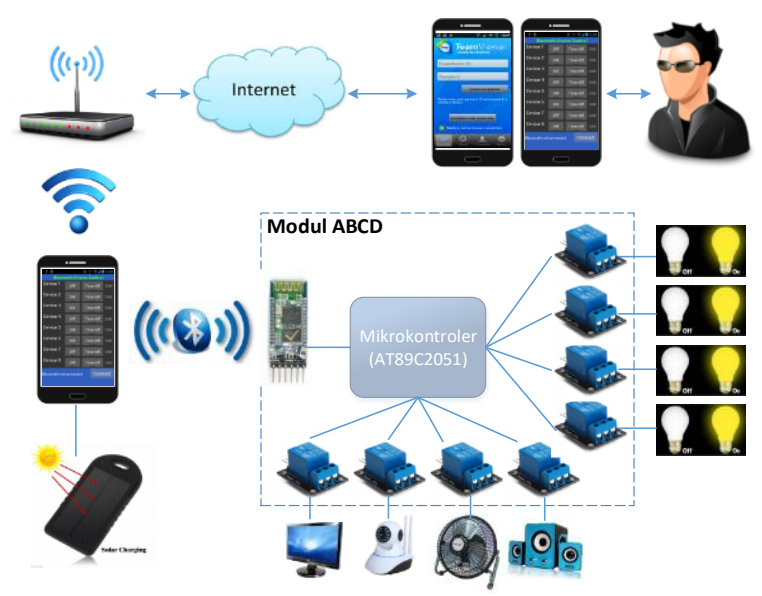

Gambar 2. HAS dari modul ABCD

Modul ABCD digunakan untuk mengendalikan relay untuk menghasilkan kondisi Normally Close (NC) menjadi Normally Open (NO). Relay dihubungkan secara pararel ke perangkat listrik sehingga perangkat listrik dapat dinyalakan melalui saklar biasa atau melalui relay. Modul ABCD mentransmisikan sinyal pulsa bluetooth dari komponen Bluetooth HC-05 dengan jangkauan sekitar $10 \mathrm{~m}$. Sebuah smartphone atau tablet android digunakan untuk mengkoneksinya app Bluetooth Control Device melalui bluetooth enable. Smartphone ini dapat mengendalikan perangkat listrik ON-OFF melalui app tersebut atau dapat melihat tampilan CCTV melalui app lainnya yang sudah disetting terhubung ke dalam jaringan LAN di router wifi terkoneksi internet.

Untuk dapat menjalankan app Bluetooth Control Device dan app CCTV melalui smartphone lainnya yang terhubung ke internet, diperlukan app yang dapat mengendalikan smartphone dari jarak jauh seperti Team Viewer atau VNC Viewer.
Dengan cara seperti ini kita dapat mengendalikan perangkat listrik dari jarak jauh. Dengan teknik seperti ini konsep HAS dapat dikembangkan menjadi sistem otomasi rumah melalui internet.

\section{B.Modul ABCD}

Perancangan modul $A B C D$ terdiri dari empat tahapan perancangan yang utama, antara lain: penentuan komponen yangdigunakan, perancangan modul utama, perancangan perangkat lunak dan penggunaan software antarmuka modul ABCD.

Komponen yang digunakan dikelompok menjadi dua yaitu komponen fisik dan komponen elektronik. Komponen fisik digunakan untuk membentuk modul android bluetooth remote control. Sedangkan komponen elektronik digunakan untuk membangun sirkuit utama (main circuit) modul android bluetooth remote control. Untuk komponen fisik tergantung dari desain masing-masing. Dan untuk komponen elektronik dapat dilihat pada Tabel 1 berikut.

Tabel 1. Rincian Komponen Elektronik

\begin{tabular}{|c|c|c|}
\hline Nama & Spesifikasi & Keterangan \\
\hline Lampu & $\begin{array}{l}15 \text { Watt (bisa } \\
\text { lebih) }\end{array}$ & $\begin{array}{l}\text { Model perangkat } \\
\text { listrik rumah } \\
\text { tinggal }\end{array}$ \\
\hline Mikrokontroler & AT89C2051 & Processor utama \\
\hline Bluetooth & HC-05 & $\begin{array}{l}\text { Koneksi antara } \\
\text { alat pengendali } \\
\text { dan smartphone }\end{array}$ \\
\hline Transistor & BC547B & \multirow{10}{*}{$\begin{array}{l}\text { Komponen main } \\
\text { modul }\end{array}$} \\
\hline Dioda & 1N4007 & \\
\hline Resistor & $2,2 \mathrm{~K} \Omega$ & \\
\hline Resistor & $1 \mathrm{~K} \Omega$ & \\
\hline Resistor & $8,2 \mathrm{~K} \Omega$ & \\
\hline LED & General red & \\
\hline Capasitor & $33 \mathrm{pF}$ & \\
\hline Capasitor & $10 \mathrm{mF}$ & \\
\hline Regulator & LM1117-3 & \\
\hline Relay & $12 \mathrm{~V}$ & \\
\hline Kabel pelangi & Isi 10,1 meter & $\begin{array}{l}\text { Transmisi } \\
\text { kontroler }\end{array}$ \\
\hline Kabel listrik & General & $\begin{array}{l}\text { Sambungan } \\
\text { listrik }\end{array}$ \\
\hline Charger & 12 Volt, $1 \mathrm{~A}$ & Sumber Daya \\
\hline Piting lampu & General & Tempat lampu \\
\hline Saklar lampu & General & $\begin{array}{l}\text { Menyalakan } \\
\text { lampu manual }\end{array}$ \\
\hline Steker & General & $\begin{array}{l}\text { Menghubungkan } \\
\text { perangkat listrik } \\
\text { ke aliran listrik }\end{array}$ \\
\hline
\end{tabular}


Perancangan modul utamaterdiri dari rangkaian yang digunakan untuk pengendalian 8 relay menggunakan mikrokontroler AT89C2051 dan Bluetooth HC-05 seperti pada Gambar 3.

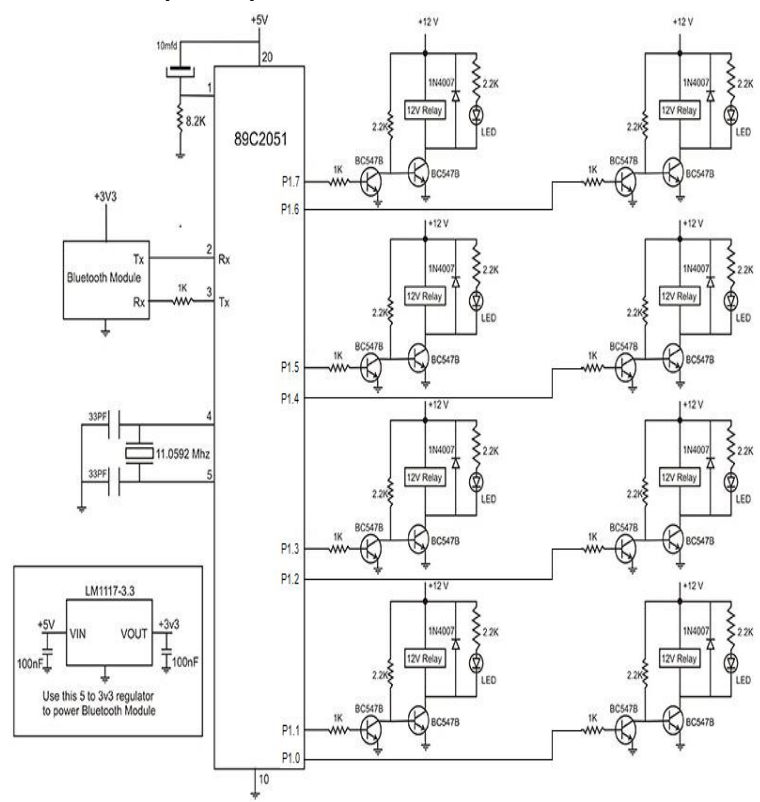

Gambar 3. Rangkaian Modul ABCD

Perancangan perangkat lunakyang dikembangkan dalam membangun sebuah modul ABCDberbasis mikrokontroler. Program dibuat dengan menggunakan bahasa $\mathrm{C}$ dan dijalankan dengan program CodeVisionAVR.

Perangkat Lunak (apps) yang digunakan di Android yaitu Bluetooth Control Device. Bentuk GUI dari aplikasi ini tampak pada Gambar 4. Aplikasi ini membolehkan kita untuk mengendalikan perangkat listrik hingga 8 buah, dapat mengatur waktu ON/OFF dan memperlihatkan waktu dimana dapat diset tiap 1 menit, 15 menit, 30 menit, 1 jam, 2 jam, dan 4 jam.

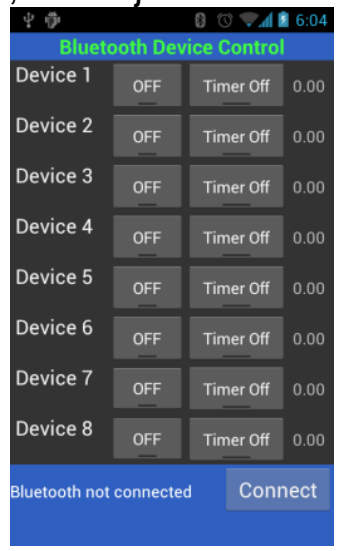

Gambar 4. Aplikasi dari Google apps
Setelah desain penempatan modul kemudian meletakkan 8 perangkat listrik yang dikemas dalam sebuah box sehingga portable, didapatkan hasil rancangan modul $A B C D 8$ relay pada gambar berikut.

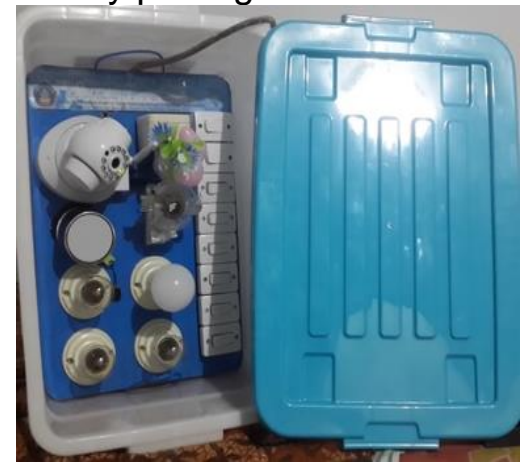

Gambar 5. Modul ABCD 8 relay

\section{Analisis Data}

Untuk mencapai tujuan penelitian secara efektif, dalam penelitian ini diterapkan analisis menggunakan konsep SMART. Konsep SMART (specific, measurable, achievable, realistic, timebased) pertama kali digunakan oleh (Doran, 1981). Konsep SMART merupakan salah satu pendekatan dalam jenis Penelitian R\&D (Research and Development).

Pengertian masing-masing istilah dapat dijelaskan sebagai berikut.

1. Spesifik (Specific)

Tujuan yang ditetapkan harus jelas dan spesifik. Jelas akan membantu menguraikan apa yang akan dilakukan, sedangkan spesifik akan membuat segala upaya dalam penelitian ini agar fokus pada target yang akan dicapai. Tujuan yang jelas dan spesifik telah dibahas pada bagian pendahuluan.

2. Terukur (Measurable)

Apa yang ingin dicapai haruslah bisa diukur, misalnya seberapa kuat, seberapa sering, seberapa banyak, atau seberapa jauh. Modul Android Bluetooth Control Device (ABCD) yang akan dibuat sebanyak 1 buah, dan akan dicoba pengontrolan untuk menyalakan lampu listrik dan perangkat listrik lainnya. Ukuran dan spesifikasi alat dan bahan yang digunakan akan dijelaskan berikutnya. Perangkat listrik yang digunakan juga terbatas untuk daya 
tertentu. Hal ini diketahui dari ukuran relay yang digunakan untuk menyalakan perangkat listrik memiliki kemampuan daya tertentu.

3. Tercapai (Achievable)

Tujuan yang ditetapkan haruslah bisa dicapai. Dengan begitu peneliti akan berkomitmen untuk mencapainya dengan sungguhsungguh. Hal yang perlu dihindari adalahjangan sampai tujuan yang ditetapkan tidak mungkin tercapai. Dalam hal ini, tujuan yang ditetapkan dalam pendahuluandiharapkan dapat dicapai. Ketercapaian tujuan akan dibahas pada bagian hasil dan pembahasan.

4. Masuk akal (Realistic)

Realistis atau masuk akal adalah hal lain yang harus dipenuhi oleh tujuan yang ingin dicapai. Hal yang perlu dihindari adalah tidak membuat tujuan yang terlalu sulit sehingga tidak mungkin untuk dicapai atau membuat tujuan yang tidak sejalan dengan keinginan atau hasrat hati. Tujuan yang tercantum dalam pendahuluan sangat realistik dan memang itulah tujuan yang diharapkan dari hasil penelitian ini.

5. Time-Based

Penelitian ini memiliki jadwal yang telah ditentukan pada tahun 2016. Dan paper ini merupakan hasil pengembangan penelitian dari hasil penelitian tersebut.

\section{Teknik Pengumpulan Data}

Dalam penelitian ini akan dilakukan pengumpulan data dari hasil pengujian untuk melihat kinerja modul yaitu:

- Pengujian modul cara manual

- Pengujian pemrograman

- Pengujian bluetooth HC-05

- Pengujian melalui internet

- Pengujian kelayakan produk

Data hasil rancangan nyata merupakan implementasi bentuk modul Android Bluetooth Control Device (ABCD) yang dapat didemokan untuk menunjukkan prinsip kerja pengendalian perangkat listrik rumah tinggal melalui android dengan koneksi bluetooth. Data pengujian perangkat lunak untuk menguji kemampuan modul ini menerima input melalui bluetooth kemudian diproses dalam mikrokontroler untuk menentukan relay yang akan dihidupkan dan relay yang akan dimatikan untuk hidup matinya perangkat listrik. Pengujian perangkat lunak di android berupa kemampuan perangkat lunak untuk disetting menyesuaikan dengan perangkat listrik yang dinyalakan dan penggunaannya dalam mengatur waktu yang diberikan. Data pengujian bluetooth berupa data koneksi yang diterima modul dari sinyal yang disampaikan melalui bluetooth. Pengujian perangkat listrik berupa pengujian secara manual dan pengujian menghidupmatikan perangkat listrik melalui perangkat android. Pengujian modul melalui internet untuk memastikan konsep HAS dapat digunakan sebagai sistem yang mampu diakses melalui internet. Sedangkan pengujian kelayakan produk untuk mendapatkan tanggapan dari beberapa responden dalam mempersiapkan produk siap jual dari modul $A B C D$ ini.

\section{HASIL DAN PEMBAHASAN}

\section{A.Pengujian Modul Secara Manual}

Modul ini dirancang untuk menghidupkan 8 buah perangkat listrik dengan cara manual atau cara meremote menggunakan smartphone android melalui koneksi bluetooth.Kerangka modul didesain dengan dimensi berukuran $45 \mathrm{~cm} \times 30 \mathrm{~cm} \times$ $28 \mathrm{~cm}$. Terdapat 4 buah lampu dan 4 buah perangkat tambahan seperti music box, kipas angin, CCTV dan penerang taman.

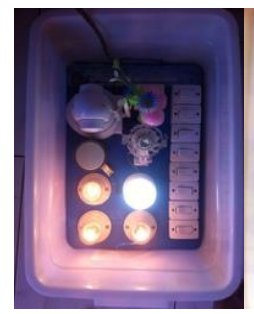

(a)

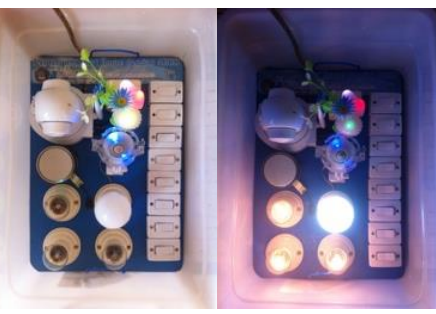

(b) (c)
Gambar 6. Pengujian secara manual Modul ABCD 8 relay: (a) Saklar Lampu $1 \mathrm{~s} / \mathrm{d} 4$ ON; (b) Perangkat Tambahan ON; (c) Semua ON

Dari hasil pengujian dengan cara manual didapatkan bahwa modul dapat berjalan dengan baik. Perangkat listrik dihubungkan melalui saklar manual untuk mendapatkan listrik dari sumber daya. 
Khusus untuk music box dengan usb drive, karena menggunakan batre lithium, maka kabel batre diputus terlebih dahulu kemudian dikoneksikan di saklar dan relay. Hasil untuk pengujian modul ABCD secara manual dapat dilihat pada Gambar 6.

\section{B.Pengujian Pemrograman}

Program disusun menggunakan bahasa $\mathrm{C}$ dan berhasil di-compile dengan compiler CodeVisionAVR versi 1.24 sebanyak 2136 line tanpa error. Pseudo programnya sebagai berikut :

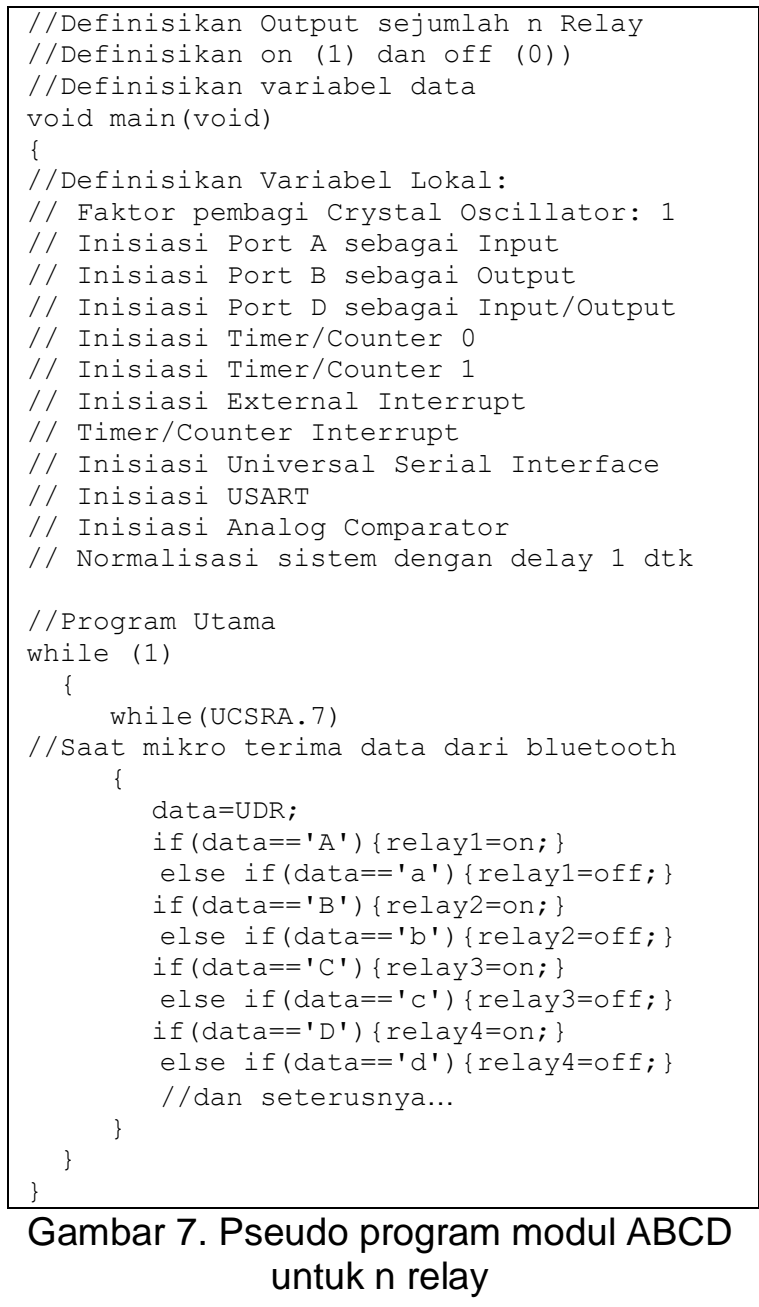

\section{Pengujian Bluetooth HC-05}

Pengujian bluetooth dilakukan untuk mengetahui apakah Bluetooth Slave (pada modul) dapat menerima informasi secara serial yang dikirim oleh Bluetooth Master (pada Smartphone) dan sejauh mana Bluetooth Master dapat mengirim data ke Bluetooth Slave yang akan dituliskan pada mikrokontroler dalam berbagai kondisi dan pengujian lapangan.

Kondisi yang dilakukan antara lain :

1) Kondisi tanpa penghalang

2) Penghalang plastik pada Bluetooth Slave

3) Penghalang plastik yang membungkus keduanya, Bluetooth Master dan Slave.

4) Tempat pengujian yang berbeda

Dalam pengujian akan dikirimkan 4 jenis data serial $\mathrm{P} 1 \mathrm{~s} / \mathrm{d}$ P4 dengan kondisi sesuai yang ditentukan pada jarak $50 \mathrm{~cm}$ hingga Bluetooth Slave tidak dapat menerima data serial yang dikirimkan oleh Bluetooth Master.

Pada bagian ini juga ditampilkan hasil dari pengujian modul ABCD secara otomatis, artinya modul sudah dikemas seperti terlihat pada pengujian secara manual, kemudian diuji kemampuan menghidupmatikan perangkat listrik melalui smartphone android.

\section{C.1 Pengujian Bluetooth Kondisi 1}

Dari hasil pengujian bluetooth dengan kondisi tanpa penghalang didapatkan data serial yang terkirim seperti terlihat pada Tabel 1.

Tabel 1. Pengujian Pengiriman Data Antara Bluetooth Master dengan Bluetooth Slave tanpa penghalang

\begin{tabular}{|c|c|c|c|c|c|c|}
\hline \multirow{2}{*}{ No. } & \multirow{2}{*}{$\begin{array}{c}\text { Jarak } \\
(\mathrm{cm})\end{array}$} & \multicolumn{4}{|c|}{ Data Terkirim } & \multirow{2}{*}{$\begin{array}{c}\% \\
\text { error }\end{array}$} \\
\hline & & P1 & $\mathrm{P} 2$ & P3 & P4 & \\
\hline 1 & 50 & $\mathrm{Ya}$ & $\mathrm{Ya}$ & $\mathrm{Ya}$ & $\mathrm{Ya}$ & $0 \%$ \\
\hline 2 & 350 & $\mathrm{Ya}$ & $\mathrm{Ya}$ & $\mathrm{Ya}$ & $\mathrm{Ya}$ & $0 \%$ \\
\hline 3 & 550 & $\mathrm{Ya}$ & $\mathrm{Ya}$ & $\mathrm{Ya}$ & Ya & $0 \%$ \\
\hline 4 & 750 & $\mathrm{Ya}$ & $\mathrm{Ya}$ & $\mathrm{Ya}$ & $\mathrm{Ya}$ & $0 \%$ \\
\hline 5 & 950 & $\mathrm{Ya}$ & $\mathrm{Ya}$ & $\mathrm{Ya}$ & $\mathrm{Ya}$ & $0 \%$ \\
\hline 6 & 1030 & $\mathrm{Ya}$ & $\mathrm{Ya}$ & $\mathrm{Ya}$ & $\mathrm{Ya}$ & $0 \%$ \\
\hline 7 & 1040 & $\mathrm{Ya}$ & Tidak & $\mathrm{Ya}$ & $\mathrm{Ya}$ & $25 \%$ \\
\hline 8 & 1045 & $\mathrm{Ya}$ & Tidak & $\mathrm{Ya}$ & $\mathrm{Ya}$ & $25 \%$ \\
\hline 9 & 1048 & $\mathrm{Ya}$ & Tidak & $\mathrm{Ya}$ & Tidak & $50 \%$ \\
\hline 10 & 1052 & Tidak & Tidak & Tidak & Tidak & $100 \%$ \\
\hline
\end{tabular}

Tabel pengujian pada Tabel 1 dapat disimpulkan bahwa jika Bluetooth Slave dengan kondisi tanpa penghalang dapat menerima data hingga 10,48 m dengan persentase tidak dapat menerima data $50 \%$. 
Jarak maksimal bluetooth masih dapat mentransmisikan data $100 \%$ yaitu pada jarak 10,33 m.

\section{C.2 Pengujian Bluetooth Kondisi 2}

Pengujian ini dilakukan dengan memberikan penghalang plastik pada Bluetooth Slave.Dari hasil pengujian bluetooth dengan kondisi ini didapatkan data serial yang terkirim seperti terlihat pada Tabel 2.

Pengujian menggunakan penghalang plastik pada Bluetooth Slave memperoleh hasil jika maksimal penerimaan data adalah $10,45 \mathrm{~m}$, dengan catatan pada jarak ini persentase kesalahan yang dapat terjadi adalah $75 \%$.

Tabel 2. Pengujian Pengiriman Data Antara Bluetooth Master dengan Bluetooth Slave menggunakan penghalang plastik pada Bluetooth Slave

\begin{tabular}{|c|c|c|c|c|c|c|}
\hline \multirow{2}{*}{ No. } & \multirow{2}{*}{$\begin{array}{c}\text { Jarak } \\
(\mathrm{cm})\end{array}$} & \multicolumn{4}{|c|}{ Data Terkirim } & \multirow{2}{*}{$\begin{array}{c}\% \\
\text { error }\end{array}$} \\
\hline & & P1 & $\mathrm{P} 2$ & P3 & P4 & \\
\hline 1 & 50 & $\mathrm{Ya}$ & $\mathrm{Ya}$ & $\mathrm{Ya}$ & $\mathrm{Ya}$ & $0 \%$ \\
\hline 2 & 350 & $\mathrm{Ya}$ & $\mathrm{Ya}$ & $\mathrm{Ya}$ & $\mathrm{Ya}$ & $0 \%$ \\
\hline 3 & 550 & $\mathrm{Ya}$ & $\mathrm{Ya}$ & $\mathrm{Ya}$ & $\mathrm{Ya}$ & $0 \%$ \\
\hline 4 & 750 & $\mathrm{Ya}$ & Ya & $\mathrm{Ya}$ & $\mathrm{Ya}$ & $0 \%$ \\
\hline 5 & 950 & $\mathrm{Ya}$ & $\mathrm{Ya}$ & $\mathrm{Ya}$ & $\mathrm{Ya}$ & $0 \%$ \\
\hline 6 & 1030 & $\mathrm{Ya}$ & $\mathrm{Ya}$ & $\mathrm{Ya}$ & $\mathrm{Ya}$ & $0 \%$ \\
\hline 7 & 1040 & Tidak & $\mathrm{Ya}$ & $\mathrm{Ya}$ & Tidak & $50 \%$ \\
\hline 8 & 1045 & Tidak & $\mathrm{Ya}$ & Tidak & Tidak & $75 \%$ \\
\hline 9 & 1048 & Tidak & Tidak & Tidak & Tidak & $100 \%$ \\
\hline 10 & 1052 & Tidak & Tidak & Tidak & Tidak & $100 \%$ \\
\hline
\end{tabular}

\section{C.3 Pengujian Bluetooth Kondisi 3}

Dari hasil pengujian bluetooth dengan kondisi Penghalang plastik yang membungkus keduanya, Bluetooth Master dan Slave didapatkan data serial yang terkirim seperti pada Tabel 3.

Penjelasan untuk Tabel 3 dapat dengan mudah dilihat dari tabel yang diberikan. Berdasarkan data pada pengujian dengan penghalang plastik yang membungkus keduanya, Bluetooth Master dan Slave, didapatkan bahwa penerimaan data Bluetooth Slave dengan kondisi terdapat plastik yang membungkus Bluetooth Master dan Bluetooth Slave maksimal pada jarak 10,4 m dengan catatan
$75 \%$ dari percobaan, Bluetooth Slave tidak dapat menerima data. Jarak maksimal koneksi bluetooth masih dapat menerima data $100 \%$ yaitu jarak $7,5 \mathrm{~m}$.

Tabel 3. Pengujian Pengiriman Data Antara Bluetooth Master dengan Bluetooth Slave menggunakan penghalang plastik pada kedua modul Bluetooth

\begin{tabular}{|c|c|c|c|c|c|c|}
\hline \multirow{2}{*}{ No. } & \multirow{2}{*}{$\begin{array}{c}\text { Jarak } \\
(\mathrm{cm})\end{array}$} & \multicolumn{4}{|c|}{ Data Terkirim } & \multirow{2}{*}{$\begin{array}{c}\% \\
\text { error }\end{array}$} \\
\hline & & P1 & P2 & P3 & P4 & \\
\hline 1 & 50 & $\mathrm{Ya}$ & $\mathrm{Ya}$ & $\mathrm{Ya}$ & Ya & $0 \%$ \\
\hline 2 & 350 & $\mathrm{Ya}$ & $\mathrm{Ya}$ & $\mathrm{Ya}$ & $\mathrm{Ya}$ & $0 \%$ \\
\hline 3 & 550 & $\mathrm{Ya}$ & $\mathrm{Ya}$ & $\mathrm{Ya}$ & $\mathrm{Ya}$ & $0 \%$ \\
\hline 4 & 750 & $\mathrm{Ya}$ & $\mathrm{Ya}$ & $\mathrm{Ya}$ & $\mathrm{Ya}$ & $0 \%$ \\
\hline 5 & 950 & $\mathrm{Ya}$ & Tidak & $\mathrm{Ya}$ & $\mathrm{Ya}$ & $25 \%$ \\
\hline 6 & 1030 & Tidak & Tidak & $\mathrm{Ya}$ & Tidak & $75 \%$ \\
\hline 7 & 1040 & Tidak & Tidak & Tidak & Tidak & $100 \%$ \\
\hline 8 & 1045 & Tidak & Tidak & Tidak & Tidak & $100 \%$ \\
\hline 9 & 1048 & Tidak & Tidak & Tidak & Tidak & $100 \%$ \\
\hline 10 & 1052 & Tidak & Tidak & Tidak & Tidak & $100 \%$ \\
\hline
\end{tabular}

C.4 Pengujian di Tempat yang Berbeda Pengujian ini juga dilakukan di tiga tempat yang berbeda untuk mengetahui jangkauan bluetooth dari Master (smartphone) ke Slave (modul).Ketiga tempat ini dipilinnya berdasarkan adanya kemungkinanterdapat halangan yang melintasyang dapat menyebabkan terganggunya transmisi data di lapangan.Gangguan tersebut dapat terjadi baik dari interferensi sinyal bluetooth dari bluetooth lainnya maupun paparan sinar matahari. Hasil dari pengujian di tempat yang berbeda didapat rata-rata jarak jangkauan 10,37 m seperti terlihat pada tabel berikut.

Tabel 4. Pengujian modul ABCD di tiga tempat berbeda

\begin{tabular}{cccc}
\hline No & $\begin{array}{c}\text { Tempat 1 } \\
(\mathrm{m})\end{array}$ & $\begin{array}{c}\text { Tempat 2 } \\
(\mathrm{m})\end{array}$ & $\begin{array}{c}\text { Tempat 3 } \\
(\mathrm{m})\end{array}$ \\
\hline Percobaan 1 & 10,23 & 10,35 & 10,26 \\
Percobaan 2 & 10,15 & 10,40 & 10,46 \\
Percobaan 3 & 10,45 & 10,09 & 10,65 \\
Percobaan 4 & 10,19 & 10,28 & 10,08 \\
Percobaan 5 & 10,24 & 10,93 & 10,77 \\
\hline Rata-rata & $\mathbf{1 0 , 2 5}$ & $\mathbf{1 0 , 4 1}$ & $\mathbf{1 0 , 4 4}$ \\
\hline
\end{tabular}




\section{C.5 Pengujian Modul secara Otomatis}

Pengujian modul ABCD secara otomatis dengan remote kontrol bluetooth dari smartphone android berhasil dengan baik seperti terlihat pada Gambar 8 . Pengguna tidak perlu menekan saklar manual untuk menyalakan perangkat listrik yang ada.
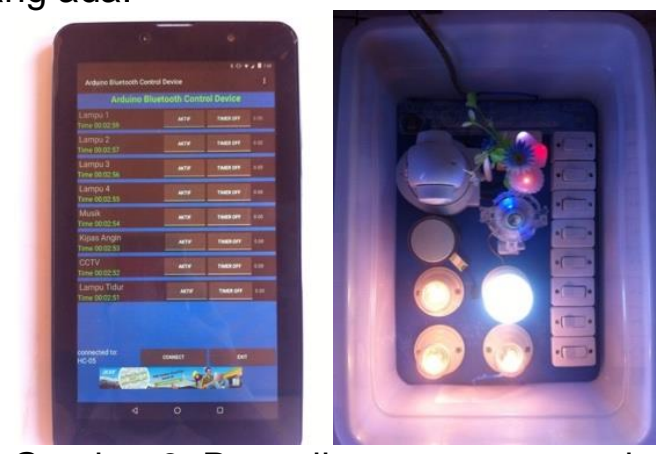

Gambar 8. Pengujian secara otomatis, semua perangkat $\mathrm{ON}$

\section{Pengujian Melalui Internet}

Pengujian melalui internet seperti desain sistem HAS pada Gambar 2 bertujuan untuk memastikan modul dan smartphone dapat disetting dan dikendalikan secara jarak jauh. Smartphone yang mengendalikan modul secara langsung sebaiknya mendapatkan suplai daya seperti menggunakan power bank bertenaga solar cell agar tetap dapat hidup walaupun pengguna di luar rumah dalam jangka waktu yang lama. Karena telah menggunakan aplikasi remote, maka app CCTV dapat juga dijalankan secara remote, dan tampilan layar CCTV juga dapat dilihat secara online.Masing-masing aplikasi remote Android dapat dilihat pada Gambar 9 berikut.
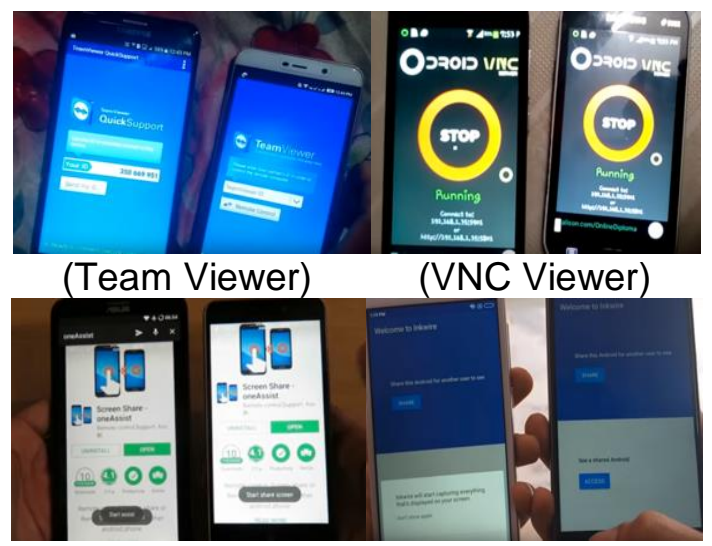

(InkWire)

(Screen Share)

Gambar 9. Aplikasi remote android

\section{E.Pengujian Kelayakan}

Pengujian kelayakan disini didahului dengan penyempurnaan modul dan buku petunjuk penggunaan untuk produknya.Kemudian modul dan buku petunjuk didemokan pada 30 orang sebagai responden yang diberikan angket untuk mendapatkan hasil kelayakan dan kepuasan serta kritik dan saran yang diperlukan.

Penilaian kategori A(Gambar 10) yaitu penilaian terhadap kegiatan praktek demo modul ABCD. Ada 10 pernyataan dalam kategori A dan semuanya pernyataan positif seperti peningkatan semangat belajar, ketertarikan mahasiswa, tanggapan senang terhadap kegiatan, pengungkapan ide, percaya dapat dipraktekkan, dan perasaan mendapat pengetahuan baru. Sehingga 10 pernyataan kategori A dapat dikelompokkan menjadi satu yang hasilnya yaitu 53\% Sangat Setuju, 39\% Setuju, 7\% Tidak Setuju, dan 1\% Sangat Tidak Setuju.

Penilaian kategori $B$ yaitu penilaian terhadap buku panduan modul $A B C D$ dengan memberikan 5 pernyataan yang terdiri dari 1 pernyataan positif dan 4 pernyataan negatif. Pernyataan positif pada ini dari pernyataan manfaat buku panduan yang diberikan. Dari pernyataan positif pada Gambar 11(a), sebanyak $70 \%$ Sangat Setuju, 20\% Setuju, 10\% Tidak Setuju, dan 0\% Sangat Tidak Setuju.Pernyataan negatif berasal dari pernyataan bahwa gaya penyajian buku panduan yang membosankan, banyak tantangan, kesulitan dan ketidakpahaman dengan isi buku panduan yang diberikan.Untuk pernyataan negatif pada Gambar 11(b) didapat hasil 0\% Sangat Setuju, 6\% Setuju, 31\% Tidak Setuju, 63\% Sangat Tidak Setuju.

Kritik dan saran yang diberikan dalam angket kelayakan modul dan buku panduan secara garis besarnya positif, seperti bentuk dukungan yang sangat baik dan dukungan untuk pengembangan selanjutnya. Walaupun ada yang menginginkan harga produk yang lebih murah, untuk sementara produk yang masih perlu pengembangan ini belum masuk dalam produksi masal karena tidak banyak orang-orang yang berkeinginan untuk menerapkannya di rumah tinggal. Namun dengan adanya respon yang positif dapat dikatakan penerapan konsep Smart Home dapat dipahami dengan baik melalui 
kegiatan praktek demo modul ABCD beserta buku panduannya.

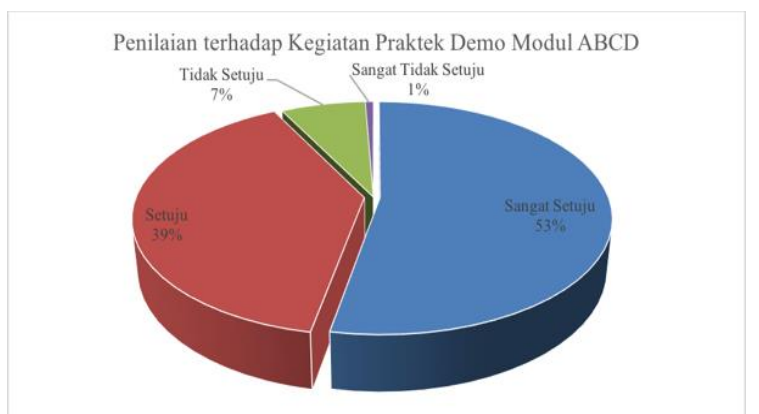

Gambar 10. Penilaian kategori A

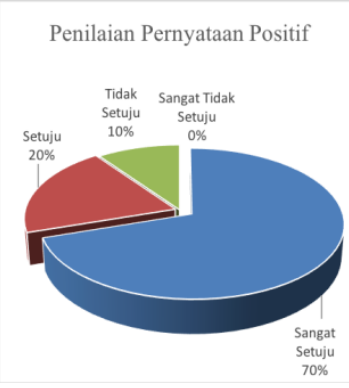

(a)

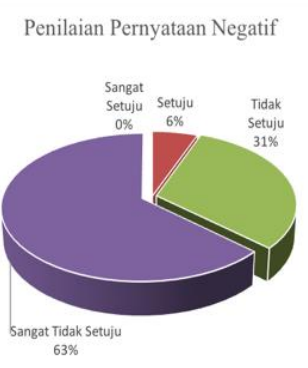

(b)
Gambar 11. Penilaian kategori B

\section{F. Pembahasan}

Bluetooth HC-05 memiliki spesifikasi kecepatan modulasi 3Mbps danfrekuensi $2,4 \mathrm{GHz}$. Dari hasil penelitian didapat jarak koneksi bluetooth HC-05 sekitar 10 meter.

Koneksi Bluetooth diuji untuk mengetahui apakah Bluetooth Slave (pada modul) dapat menerima informasi secara serial yang dikirim oleh Bluetooth Master (pada Smartphone) dan sejauh mana Bluetooth Master dapat mengirim data ke Bluetooth Slave yang akan dituliskan pada mikrokontroler dalam berbagai kondisi dan pengujian lapangan. Kondisi yang dilakukan antara lain : 1) Kondisi tanpa penghalang; 2) Penghalang plastik pada Bluetooth Slave; 3) Penghalang plastik yang membungkus keduanya, Bluetooth Master dan Slave; dan Tempat pengujian yang berbeda.

Bluetooth dengan kondisi tanpa penghalang dapat menerima data hingga $10,48 \mathrm{~m}$ dengan persentase tidak dapat menerima data $50 \%$. Bluetooth dengan kondisi penghalang plastik pada Bluetooth Slave didapat hasil maksimal penerimaan data adalah 10,45 $\mathrm{m}$ dengan persentase kesalahan $75 \%$. Bluetooth dengan kondisi terdapat plastik yang membungkus masingmasing Bluetooth hasil maksimal pada jarak $10,30 \mathrm{~m}$ dengan catatan $75 \%$ kesalahan dari percobaan.

Jarak maksimal komunikasi data pada Bluetooth dapat bekerja secara optimal dengan kondisi tanpa penghalang adalah $10,33 \mathrm{~m}$. Sedangkan di atas 10,33 m, bluetooth sudah tidak dapat berkomunikasi $100 \%$. Hal ini sesuai dengan spesifikasi bluetooth HC-05 yaitu jarak jangkauan $10 \mathrm{~m}$.

Berdasarkan konsep SMART disini dapat dijelaskan sebagai berikut. Specific dari segi alat modul sudah ditentukan, koneksi bluetooth, aplikasi pada smartphone sangat spesifik yaitu Bluetooth Control Device. Measurable dalam kemampuannya menyalakan lampu, setiap saklar untuk menyalakan 1 lampu, begitu juga setiap tombol Device untuk menyalakan 1 lampu. Achievable dalam hal ini diperoleh hasil penyalaan lampu untuk masing-masing saklar dan tombol pada aplikasi sesuai dengan yang diharapkan. Realistic disini adalah modul ini setelah diuji di lab dapat diaplikasikan secara riil untuk pengendalian perangkat listrik rumah tinggal. Time-based disini dapat dilihat dari aplikasi yang digunakan terdapat kontrol waktu untuk menyalakan lampu secara otomatis dengan pilihan penyalaan dalam waktu 1 menit, 15 menit, 30 menit, 1 jam, 2 jam, dan 4 jam.

Penilaian dengan menggunakan angket juga dilakukan untuk menguji kelayakan dari modul dan panduannya. Hasil yang didapatkan bahwa 92\% responden setuju atau merespon baik terhadap kegiatan praktek demo modul $A B C D$ dan hanya $8 \%$ yang kurang berminat dengan kegiatan praktek tersebut. Sedangkan untuk penilaian terhadap buku panduan modul ABCD dapat dikatakan 94\% responden paham, senang dan tidak sulit memahami isi buku panduan, sedangkan $6 \%$ responden merasa sebaliknya.

Konsep Home Automation System (HAS) yang ditawarkan disini selain memudahkan pengguna dalam mengendalikan perangkat listrik saat berada di rumah, juga diharapkan dapat memudahkan pengguna saat bepergian dalam jangka waktu lama. Sehingga perangkat listrik di rumah dapat dikendalikan walaupun pengguna berada di tempat yang 
jauh, karena sudah dilakukan remote smartphone Androidnya melalui internet. Dengan demikian konsep ini dapat meminimalkan terjadinya pencurian pada rumah yang ditinggal jauh oleh pemiliknya karena pemiliknya dapat menyalakan perangkat listrik di rumahnya sewaktu-waktu walaupun sedang bepergian.

\section{SIMPULAN DAN SARAN}

Kesimpulan yang dapat diambil dalam penelitian ini antara lain:

1. Bluetooth HC-05 merupakan bluetooth generasi ke-2 dengan kecepatan modulasi $3 \mathrm{Mbps}$, frekuensi $2,4 \mathrm{GHz}$, dan jarak maksimum $10 \mathrm{~m}$.

2. Hasil pengukuran pengiriman 4 jenis data sinyal bluetooth dengan 3 kondisi berbeda diketahui bahwa jarak maksimum bluetooth 100\% dapat menerima data tanpa halangan sebesar $10,33 \mathrm{~m}$.

3. Hasil percobaan 5 kali pada 3 tempat yang berbeda didapatkan rata-rata jarak maksimal yang masih memungkinkan koneksi bluetooth ini berjalan sempurna secara umum sebesar $10,37 \mathrm{~m}$.

4. Modul ABCD untuk Home Automation System (HAS) disini yaitu modul ABCD untuk 8 relay yang didesain secara portable dan dapat bekerja dengan baik secara manual dan otomatis malalui remote bluetooth. Untuk dapat menjalankan modul secara online dapat menggunakan app remote android seperti Team Viewer, VNC Viewer, InkWire, atau Screen Share.

5. Dari hasil uji kelayakan disimpulkan bahwa modul ABCD dan buku panduannya dinyatakan layak dan baik secara pemahaman terhadap praktek modul dan isi dari buku panduan.

Saran yang dapat diberikan dalam penelitian lanjutan adalah penelitian dengan konsep HAS diharapkan hasil produknya dapat diproduksi untuk digunakan ke rumah tinggal. Penelitian seperti ini dapat diterapkan tidak hanya untuk pengendalian perangkat listrik rumah (AC), namun juga pengendalian perangkat listrik DC karena relay pada dasarnya saklar yang diatur sesuai adanya arus yang mengalir di dalamnya.

\section{DAFTAR PUSTAKA}

Demeure, A., Caffiau, S., Elias, E., \& Roux, C. (2015). Building and Using Home Automation Systems: A Field Study. ISEUD. https://doi.org/10.1007/978-3319-18425-8_9

Doran, G. T. (1981). There's a S.M.A.R.T. way to write managements's goals and objectives. Management Review, 70(11), 35-36. https://doi.org/10.1177/004057368303 900411

Gitakarma, M. S., Indrawan, G., \& Adiarta, A. (2016). Pengembangan Modul Android Bluetooth Remote Control Relay sebagai Sistem Otomasi Rumah Tinggal. In Proceeding of Seminar Nasional Riset Inovatif (SENARI) ke-4, Undiksha (pp. 170-177).

Harikrishnan, D., Nikhil, S., Roy, M. T., \& Mathew, S. V. (2017). Android Based Home Automation Using Bluetooth. Intl. Journal of Adv. Research in Electrical, Electronics \& Instrument. Eng., 6(4), 2605-2609.

https://doi.org/10.15662/IJAREEIE.201 7.0604073

Pandya, B., Mehta, M., Jain, N., \& Kadam, S. (2016). Android Based Home Automation System Using Bluetooth \& Voice Command. International Research Journal of Engineering and Technology (IRJET), 03(04), 13371342.

Panth, S., \& Jivani, M. (2013). Home Automation System (HAS) using Android for Mobile Phone. Intl. Journal of Electronics and Computer, 3(1).

Ramlee, R. A., Othman, M. A., Leong, M. H., Ismail, M. M., \& Ranjit, S. S. S. (2013). Smart Home System Using Android Application. In Intl. Conf. of Information and Communication Technology (ICoICT) (pp. 277-280). https://doi.org/https://doi.org/10.1109/l ColCT.2013.6574587

Sriskanthan, N., Tan, F., \& Karande, A. (2002). Bluetooth based Home Automation System. Microprocessors and Microsystems, 26(6), 281-289. https://doi.org/10.1016/S01419331(02)00039-X 